\title{
Potensi Hama Pomacea canaliculata Sebagai Antibakteri Terhadap Patogen Xanthomonas oryzae pv oryzae
}

\author{
Irwanto Sucipto', Ahmad Ilham Tanzil'2, Wildan Muhlison ${ }^{3}$ \\ ${ }^{1}$ Prodi Agroteknologi, Fakultas Pertanian, Universitas Jember, Indonesia. Email: irwanto.sucipto@unej.ac.id \\ ${ }_{2}^{2}$ Prodi Agroteknologi, Fakultas Pertanian, Universitas Jember, Indonesia. Email: aitanzil@unej.ac.id \\ 3 Prodi Agroteknologi, Fakultas Pertanian, Universitas Jember, Indonesia. Email: wildan.muhlison@unej.ac.id
}

\begin{abstract}
Xanthomonas oryzae pv. oryzae (Xoo) is one of the important diseases in rice. The key to Xoo's primary control is using disease-free or treated seeds and crop rotation. However, the relevance of using certified seeds or seedlings will be reduced if there is a combination of main pest attacks that help the entry of these pathogens into the plant, one example is the golden snail from the mollusca group. Based on several research sources, the mollusca group in marine areas is an untapped source and can be used to find new ingredients as antimicrobials. Starting from this, it can be seen that one of the important pests in rice, namely golden snails (Pomacea canaliculata), is part of the mollusca phylum which can actually be used as an antimicrobial. Given that $P$. canaliculata is one of the important pests in rice which is very destructive, this can be one of the advantages, namely that the pest will not return to the pest status but will also hold the status as an antimicrobial raw material used in rice plants as well. This is an innovation in itself in the field of controlling bacterial leaf blight because in addition to controlling the disease, the important pests of golden snails can be controlled. Chitosan and Antimicrobial Peptides (AMPs) were obtained by extracting golden snails using different techniques. A total of eight treatments were used in this study, namely negative control $(\mathrm{KON})$, positive control (KKT), Chitosan (KT) with 3 concentrations, namely $0.2 \%, 0.4 \%, 0.6$ and Antimicrobial Peptides (AA) with 3 concentrations. $1 \%, 3 \%$, $5 \%$. The method used is the paper disc diffusion method to determine the inhibitory power of Chitosan and Antimicrobial Peptides (AMPs) against pathogenic bacteria. Treatments that have an effect will be further tested using the Duncan test at the level of $a=0.05$. Each chitosan and AMPs treatment at each concentration showed a different level of inhibition. The highest inhibition was seen in the AMPs treatment with a concentration of $1 \%$. It was noted that the increase in concentration was inversely related to the inhibitory power in each treatment. The conclusion from this study is that chitosan and AMPs treatment has excellent potential as environmentally friendly antibacterials with abundant raw materials as indicated by the best treatment, namely AMPs $1 \%$. The increasing number of new research related to environmentally friendly antibacterials will be a turning point in the world of antimicrobial development.
\end{abstract}

Keywords: antimicrobial, environmentally friendly, golden snail, mollusca, resistance 


\begin{abstract}
ABSTRAK
Xanthomonas oryzae pv. oryzae (Xoo) merupakan salah satu penyakit penting pada padi. Kunci pengendalian utama Xoo adalah menggunakan benih bebas penyakit atau benih yang diperlakukan dan rotasi tanaman. Namun relevansi penggunaan benih atau bibit bersertifikasi akan menjadi berkurang jika terdapat kombinasi serangan hama utama yang membantu masuknya patogen ini ke dalam tanaman, salah satu contohnya adalah keong mas dari golongan mollusca. Berdasarkan beberapa sumber penelitian, golongan mollusca yang berada di daerah laut merupakan sumber yang tidak dimanfaatkan dan dapat digunakan untuk mencari kandungan baru sebagai antimikroba. Bertolak dari hal tersebut maka dapat dilihat bahwa salah satu hama penting di padi yaitu keong mas (Pomacea canaliculata) merupakan bagian dari filum mollusca yang sebenarnya dapat dimanfaatkan sebagai antimikroba. Mengingat bahwa $P$. canaliculata merupakan salah satu hama penting pada tanaman padi yang sangat merusak maka hal tersebut dapat menjadi salah satu keuntungan yaitu hama tersebut tidak akan menyandang status hama kembali melainkan akan menyandang status sebagai bahan baku antimikroba yang digunakan pada tanaman padi juga. Hal tersebut menjadi suatu inovasi tersendiri di bidang pengendalian penyakit hawar daun bakteri karena selain dapat mengendalikan penyakit, hama penting keong mas dapat terkendalikan. Chitosan dan Antimicrobial Peptides (AMPs) didapatkan dengan cara melakukan ekstraksi dari keong mas dengan teknik yang berbeda. Sebanyak delapan perlakuan digunakan dalam penelitian ini yaitu kontrol negative (KON), kontrol positif (KKT), Chitosan (KT) dengan 3 konsentrasi yaitu 0,2\%, 0,4\%, 0,6 dan Antimicrobial Peptides (AA) dengan 3 konsentrasi $1 \%, 3 \%, 5 \%$. Metode yang digunakan adalah Metode Difusi Cakram kertas untuk mengetahui daya hambat dari Chitosan dan Antimicrobial Peptides (AMPs) terhadap bakteri patogen. Perlakuan yang berpengaruh akan diuji lanjut dengan menggunakan uji Duncan pada pada taraf $a=0,05$. Tiap perlakuan chitosan dan AMPs pada tiap konsentrasi menunjukkan tingkat penghambatan yang berbeda. Penghambatan tertinggi terlihat pada perlakuan AMPs dengan konsentrasi 1\%. Tercatat bahwa peningkatan konsentrasi berbanding terbalik terhadap daya hambat di setiap perlakuan. Kesimpulan yang didapat pada penelitian ini adalah perlakuan chitosan dan AMPs memiliki potensi yang sangat baik sebagai antibakteri ramah lingkungan dengan bahan baku melimpah yang ditunjukkan oleh perlakuan terbaik yaitu AMPs 1\%. Semakin banyaknya penelitian baru terkait antibakteri ramah lingkungan akan menjadi titik balik dalam dunia pengembangan antimikroba.
\end{abstract}

Kata Kunci: antimikroba, keong mas, mollusca, ramah lingkungan, resistensi

\title{
PENDAHULUAN
}

Selama dua dekade, industri farmasi telah cukup sukses dalam mengatasi permasalahan yang diakibatkan oleh faktor tunggal yang menyebabkan resistensi. Berbeda terhadap mekanisme resisten yang diakibatkan oleh faktor yang terdiri dari banyak bagian, kandungan antimikroba masih sangat terbatas. Oleh karena itu terdapat ketertarikan yang sangat penting dalam mencari kandungan antimikroba yang baru dengan resiko yang rendah terhadap lingkungan dan tingkat toksikologinya dimana tidak terdapat pengembangan tingkat resistensi oleh patogen (Chellaram, Gnanambal, \& Edward, 2004). Perihal tersebut juga dapat diadopsi pada dunia pertanian dimana mulai dicari bahan aktif antimikroba yang lebih ramah 
lingkungan dan tidak berbahaya bagi manusia. Pal and McSpadden Gardener (2006) menambahkan terdapat perubahan pola pikir manusia terhadap penggunaan pestisida dalam pertanian akibat residu pestisida yang menyebabkan polusi lingkungan.

Khususnya di wilayah Asia, tanaman padi merupakan tanaman pangan terpenting sehingga permintaan akan padi selalu meningkat (Khush \& Jena, 2009). Hal tersebut meningkatkan perhatian kesehatan tanaman terutama untuk tanaman pangan kaitannya dengan penggunaan pestisida. Meskipun padi merupakan tanaman yang sudah lama dibudidayakan tetapi banyak permasalahan OPT (Organisme Pengganggu Tanaman) yang masih belum terselesaikan sampai saat ini. Hawar Daun Bakteri (HBD) yang disebabkan oleh Xanthomonas oryzae pv. oryzae (Xoo) merupakan salah satu contoh penting penyakit pada padi (Wahyudi, Meliah, \& Nawangsih, 2011). Banyak bakterisida yang bermunculan di pasaran tetapi tidak satupun dapat menyelesaikan secara tuntas keberadaan patogen tersebut. Inovasi pencarian bahan aktif antimikroba harusnya menjadi kunci untuk permasalahan tersebut. Agrios (2005) menambahkan bahwa kunci pengendalian utama adalah menggunakan benih bebas penyakit atau benih yang diperlakukan dan rotasi tanaman. Namun relevansi penggunaan benih atau bibit bersertifikasi akan menjadi berkurang jika terdapat kombinasi serangan hama yang membantu masuknya patogen ini ke dalam tanaman, salah satu contohnya adalah keong mas dari golongan mollusca.

Mollusca sendiri merupakan salah satu filum yang diketahui dengan baik dan (setelah Arthropoda) filum terbesar kedua pada kingdom animalia, memiliki sekitar 100.000 spesies yang masih ada dan sekitar 70.000 spesies yang telah dideskripsikan sebagai fosil. (Haszprunar, 2001). Selain image keong mas di pertanaman padi sebagai hama, Chellaram et al. (2004) mengatakan mollusca yang berada di daerah laut merupakan sumber yang tidak dimanfaatkan dan dapat digunakan untuk mencari kandungan baru sebagai antimikroba. Berdasarkan laporan dari beberapa penelitian dilaporkan bahwa kandungan ekstrak dari mollusca seperti Parerythropodium fulvum fulvum (Kelman, Kuhmaro, Loya, Kashman, \& Benayahu, 1998), Sepia sp.,Loligo sp. dan Tibia insulaechorab-curta (Degiam \& Abas, 2010), Thais tissoti, Babylonia spirata (Kumaran, Bragadeeswaran, \& Thangaraj, 2011) memiliki aktivitas antimikroba. Bertolak dari hal tersebut maka dapat dilihat bahwa salah satu hama penting di padi yaitu keong mas (Pomacea canaliculata) merupakan bagian dari filum mollusca yang sebenarnya dapat dimanfaatkan sebagai antimikroba. Mengingat bahwa $P$. canaliculata merupakan salah satu hama penting pada tanaman padi yang sangat merusak maka hal tersebut dapat menjadi salah satu keuntungan yaitu hama tersebut tidak akan menyandang status hama kembali melainkan akan menyandang status sebagai bahan baku antimikroba yang digunakan pada tanaman padi juga. Hal tersebut menjadi suatu inovasi tersendiri di bidang pengendalian penyakit hawar daun bakteri karena selain dapat mengendalikan penyakit, hama penting keong mas dapat terkendalikan. Untuk dapat mewujudkan hal tersebut maka peneliti melakukan penelitian yang bertujuan untuk menemukannya inovasi bahan aktif baru yang ekfektif dan efisien sebagai antibakteri pada tanaman padi sebagai pengganti pestisida kimia komersial. 


\section{METODE PENELITIAN}

Penelitian dilaksanakan di Laboratorium Agroteknologi Fakultas Pertanian Universitas Jember. Isolat bakteri yang digunakan Xanthomonas oryzae pv. oryzae didapat dari koleksi Laboratorium Biologi Fakultas MIPA, Universitas Jember.

\section{Prosedur Penelitian}

Persiapan Larutan AMPs dari Keong Mas (P. canaliculata). Proses pembuatan larutan fermentasi keong mas menggunakan keong mas lengkap dengan cangkang dan buah pepaya matang. Perbandingan bahan larutan fermentasi yang digunakan adalah 10:1. Fermentasi diawali dengan merebus keong mas hingga masak kemudian setelah masak, kemudian keong mas didinginkan dan ditiriskan. Setelah keong mas ditiriskan maka keong mas beserta cangkang ditumbuk hingga cangkang hancur dan diaduk rata dengan pepaya. Semua bahan yang siap dimasukkan pada wadah yang tertutup rapat dan disimpan selama 30-40 hari. Setelah fermentasi berakhir maka cairan fermentasi disaring sehingga terpisah dengan ampas nya.

Persiapan Chitosan yang Berasal dari Cangkang Keong Mas (P. canaliculata). Proses pembuatan chitosan menggunakan metode yang telah dilakukan oleh Azam Baihaqi (2017) yaitu mengekstraksi chitosan melalui tahap deproteinasi, tahap demineralisasi dan tahap deasetilasi. Setiap proses diikuti dengan tahap pencucian, pembilasan, penetralan $\mathrm{pH}$, dan pengeringan.

Persiapan Suspensi Bakteri X. oryzae pv. oryzae. X. oryzae pv. oryzae berumur 1 hari pada media Nutrient Agar diinkubasi ke dalam media Nutrient broth $10 \mathrm{ml}$ selama 12 jam. Setelah $12 \mathrm{jam}, 100 \mu \mathrm{l}$ biakan X. oryzae pv. oryzae diencerkan ke dalam 9,9 ml media Nutrient Broth (NB). Sebanyak $100 \mu \mathrm{l}$ diambil dari hasil pengenceran untuk ditumbuhkan pada media NA dengan metode sebar menggunakan glass beed steril kemudian dikeringanginkan.

Pengujian ekstrak keong mas terhadap penghambatan pertumbuhan $X$. oryzae pv. oryzae secara in vitro menggunakan delapan perlakuan yaitu kontrol negative (KON), kontrol positif (KKT), Chitosan (KT) dengan 3 konsentrasi yaitu 0,2\%, 0,4\%, 0,6 dan Antimicrobial Peptides (AA) dengan 3 konsentrasi 1\%,3\%,5\%. Metode yang digunakan dengan Metode Difusi Cakram kertas yang mengacu pada metode Ambarwati (2007); Khoirunnisya (2009). Cakram kertas berbentuk lingkaran dengan diameter $10 \mathrm{~mm}$ disterilkan dalam oven. Sebanyak lima kertas cakram steril dengan empat ulangan diletakkan di atas media berpatogen. Di atas kertas cakram pertama diteteskan $20 \mu \mathrm{l}$ ekstrak keong mas, di atas kertas saring kedua diteteskan $20 \mu$ larutan fermentasi keong mas, di atas kertas saring berikutnya diteteskan 20 $\mu \mathrm{l}$ ekstrak chitosan yang berasal dari cangkang keong mas, kertas saring berikutnya diteteskan $20 \mu \mathrm{l}$ larutan chlorampenicol sebagai perlakuan kontrol positif dan yang terakhir dibagian tengah diteteskan $20 \mu \mathrm{l}$ media NB sebagai perlakuan kontrol negatif. Pengamatan penghambatan pertumbuhan $X$. oryzae pv. oryzae oleh ekstrak tumbuhan dilakukan 24 jam setelah perlakuan dengan mengukur diameter lebar zona bening yang terbentuk di sekitar kertas saring (Khoirunnisya, 2009).

Rancangan percobaan yang dilakukan adalah Rancangan Acak Lengkap (RAL). Data perlakuan yang berpengaruh diuji lanjut dengan uji Duncan pada taraf $\alpha=0,05$ menggunakan program SPSS. 


\section{HASIL DAN PEMBAHASAN}

\section{Aktivitas Antibakteri Chitosan dan Antimicrobial Peptides (AMPs) asal Keong Mas}

Pengujian aktivitas antibakteri dari Chitosan dan Antimicrobial Peptides (AMPs) asal keong mas dilakukan dengan mengevaluasi berdasarkan zona bening yang terbentuk di sekitar daerah kertas cakram yang telah diberi beberapa perlakuan. Hal ini bertujuan untuk mengetahui apakah antimicrobial peptides (AMPs) (Gambar 1) dan chitosan (Gambar 2) asal keong mas memiliki kandungan antibakteri. Chitosan merupakan biopolimer polisakarida yang menggabungkan satu set unik dari versatile physicochemical dan karakteristik biologis yang memungkinkan untuk berbagai aplikasi (Raafat, Von Bargen, Haas, \& Sahl, 2008). Sesuai dengan penelitian yang dilakukan oleh Rabea, Badawy, Stevens, Smagghe, and Steurbaut (2003) yang mengatakan chitosan yang biopolimer hidrofilik diperoleh secara industri melalui proses $N$-deacetylation dari kitin, dapat digunakan sebagai agen antimikroba. Pada penelitian ini proses $N$-deacetylation merupakan salah satu dari proses pembuatan chitosan. Berbeda dengan chitosan, AMPs merupakan molekul imun bawaan yang menunjukkan aktivitas penghambatan terhadap berbagai mikroba, termasuk bakteri, jamur, virus, dan protozoa. (Gabere \& Noble, 2017). Zona bening yang ditunjukkan pada Gambar 1 dan Gambar 2 menunjukkan adanya bukti terhadap aktivitas antibakteri, meskipun terdapat tingkat perbedaan penghambatan di tiap perlakuan.

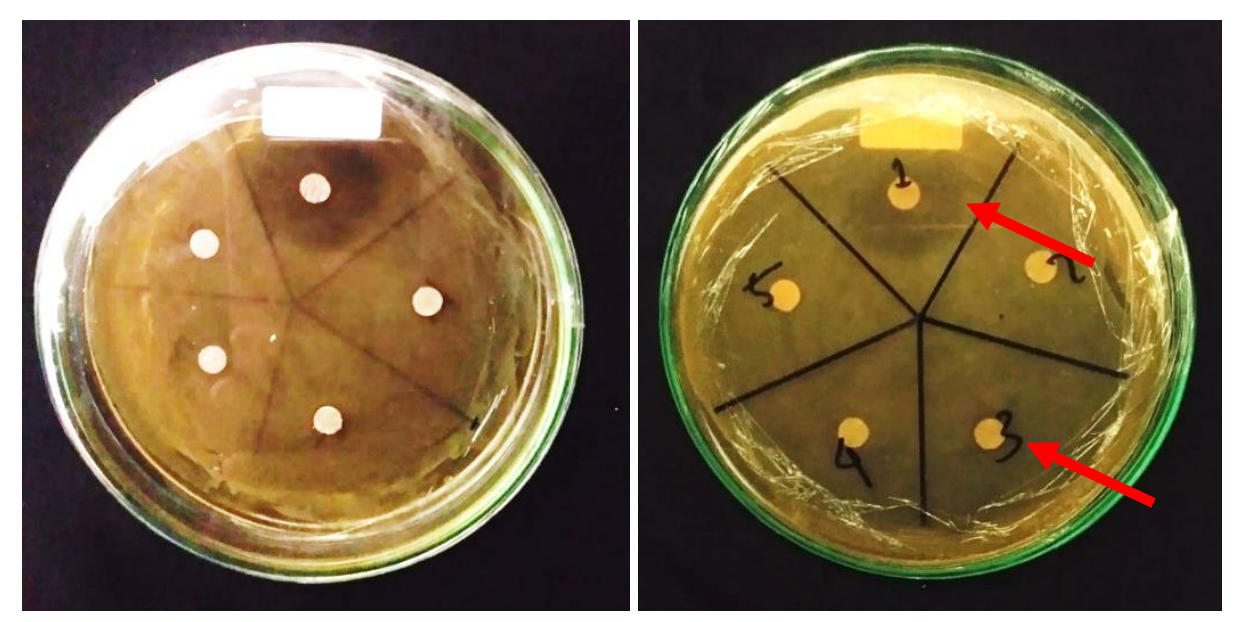

Gambar 1. Zona bening yang terlihat pada perlakuan AMPs: perlakuan $1(\mathrm{~K}+)$ sebesar $2.5 \mathrm{~cm}$ dan pada perlakuan 2 (K-), 4 (3\%) dan 5 (5\%) tidak muncul zona bening, pada perlakuan 3

(1\%) sebesar $1.9 \mathrm{~cm}$ (pengambilan foto menggunakan mode makro) 

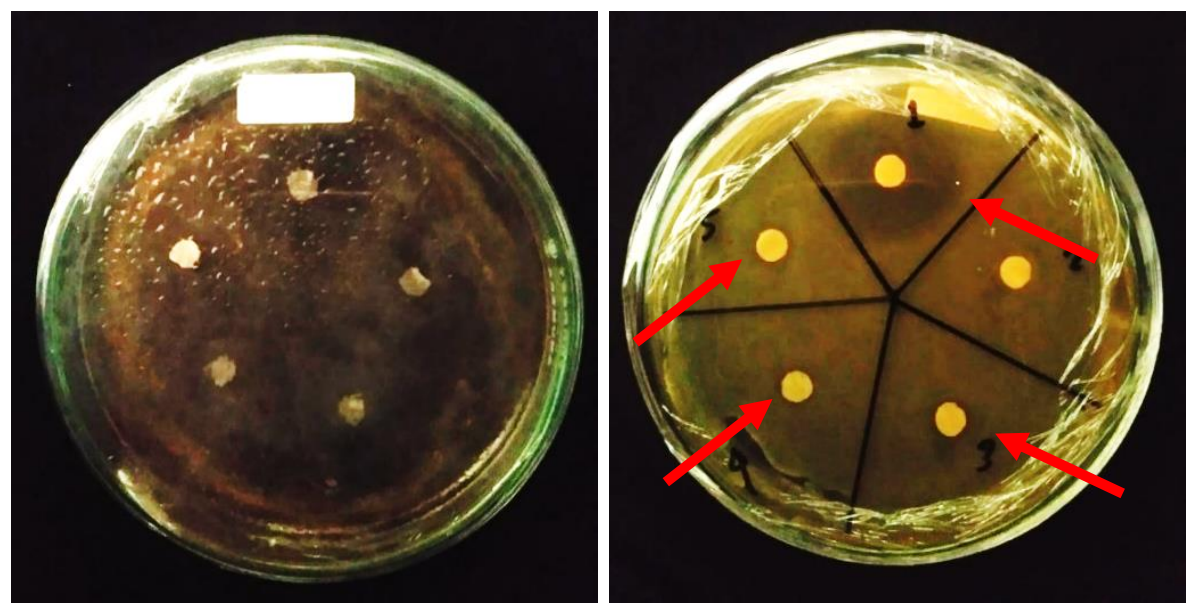

Gambar 2. Zona bening yang terlihat pada perlakuan chitosan: perlakuan $1(\mathrm{~K}+)$ sebesar 2.5 $\mathrm{cm}$, pada perlakuan $2(\mathrm{~K}-)$ tidak muncul zona bening, pada perlakuan $3(0,2 \%)$ sebesar $0.7 \mathrm{~cm}$, pada perlakuam $4(0,4 \%)$ sebesar $0,6 \mathrm{~cm}$ dan perlakuan $5(0,6 \%)$ sebesar $0.6 \mathrm{~cm}$ (pengambilan foto menggunakan mode makro).

Satu cawan petri terdiri dari lima kertas cakram yang terdiri dari lima perlakuan yaitu perlakuan chitosan dengan berbagai konsentrasi, perlakuan asam amino dengan berbagai konsentrasi, kontrol negatif dan kontrol positif. Konsentrasi tinggi yang dianjurkan adalah 5\%-6\% karena konsentrasi tersebut merupakan ambang batas tingkat efisien untuk memproduksi sebuah pestisida alami. Berdasarkan hasil uji daya hambat, semua larutan uji baik chitosan atau AMPs memiliki aktivitas daya hambat dengan persentase daya hambat yang berbeda (Tabel 2). Menurut hasil analisis ragam, daya hambat tertinggi yang dari perlakuan selain kontrol positif ditunjukkan oleh perlakuan Chitosan 0,2\%, sedangkan perlakuan yang lain mulai dari asam amino berbagai konsentrasi sampai dengan chitosan $0,4 \%$ dan $0,6 \%$ tidak berbeda nyata meskipun tiap perlakuan tersebut menunjukkan aktivitas antibakteri. Hal tersebut menunjukkan bahwa tiap perlakuan memiliki potensi yang besar sebagai antibakteri meskipun kemampuan antibakterinya tidak melampaui aktivitas antibakteri dari antibiotik chloramfenicol. Beberapa laporan penelitian menunjukan bahwa kandungan ekstrak dari mollusca seperti Parerythropodium fulvum fulvum (Kelman et al., 1998), Sepia sp.,Loligo sp. dan Tibia insulaechorab-curta (Degiam \& Abas, 2010), Thais tissoti, Babylonia spirata (Kumaran et al., 2011) memiliki aktivitas antimikroba.

\section{Pengaruh Chitosan dan Antimicrobial Peptides (AMPs) asal Keong Mas terhadap pertumbuhan Xanthomonas oryzae pv. oryzae secara invitro}

Hasil uji sidik ragam satu arah pada data penghambatan pertumbuhan bakteri dengan tingkat

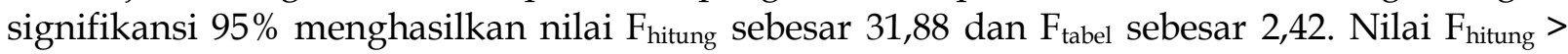
$\mathrm{F}_{\text {tabel }}$ memberikan kesimpulan bahwa terdapat perbedaan yang signifikan antara perlakuan yang diberikan terhadap hasil penghambatan pertumbuhan bakteri. Hasil uji Duncan Multiple Range Test (DMRT) pada Tabel 2 juga menunjukkan perbedaan yang signifikan di tiap penghambatan pertumbuhan bakteri yang dicirikan notasi huruf yang berbeda ( $a, b, c$ dan $d)$. 
Tabel 1. Hasil Uji ANOVA

\begin{tabular}{lcrcccc}
\hline \multicolumn{1}{c}{ Source of Variation } & SS & df & MS & $F$ & P-value & F crit \\
\hline Between Groups & 22225.86 & 7 & 3175.123 & 31.88618 & $1.17 \mathrm{E}-10$ & 2.422629 \\
Within Groups & 2389.843 & 24 & 99.57679 & & & \\
& & & & & & \\
Total & 24615.7 & 31 & & & & \\
\hline
\end{tabular}

Pengujian pengaruh chitosan dan antimicrobial peptides (AMPs) asal keong mas terhadap pertumbuhan Xanthomonas oryzae pv. oryzae secara invitro menunjukkan terdapat aktivitas penghambatan pada setiap kosentrasi di tiap perlakuan (Tabel 2). Delapan perlakuan yang digunakan adalah perlakuan kontrol negatif $(\mathrm{K}-)$, kontrol positif $(\mathrm{K}+)$ dengan menggunakan bakterisida, perlakuan AMPs dengan kode AA 1\%, AA 3\%, AA 5\%, perlakuan chitosan dengan kode $\mathrm{KT} 0,2 \%$, KT 0,4\%, KT 0,6\%. Beda nyata tertinggi ditunjukkan oleh perlakuan AA $1 \%$ dimana menunjukkan aktivitas penghambatan yang tinggi terhadap pertumbuhan bakteri Xanthomonas oryzae pv. oryzae. Aktivitas penghambatan pada tiap perlakuan ditunjukkan oleh munculnya zona bening pada perlakuan tersebut (Gambar 1 dan Gambar 2).

Tabel 2. Hasil uji Duncan Multiple Range Test (DMRT) pada variasi Chitosan

\begin{tabular}{cccccc}
\hline Perlakuan & $\mathrm{n}$ & $\mathrm{a}$ & $\mathrm{b}$ & $\mathrm{c}$ & $\mathrm{d}$ \\
\hline Kontrol (-) & 4 & .0000 & & & \\
AA 5\% & 4 & & 13.6667 & & \\
AA 3\% & 4 & & 14.6667 & & \\
KT 0,6\% & 4 & & & 30.4206 & \\
KT 0,4\% & 4 & & & 31.3095 & \\
KT 0,2\% & 4 & & & 39.8810 & \\
AA 1\% & 4 & & & & 73.5000 \\
Kontrol (+) & 4 & & & & 78.8509 \\
\hline
\end{tabular}

Subset for alpha $=0.05$

* AA adalah perlakuan antimicrobial peptides (AMPs), KT adalah perlakuan chitosan, Kontrol (-) adalah perlakuan kontrol dengan menggunakan air steril, Kontrol $\left(_{+}^{+}\right.$adalah perlakuan kontrol dengan menggunakan antibiotik chloramphenicol. Angka-angka pada kolom yang sama yang diikuti oleh huruf yang sama tidak berbeda nyata pada taraf uji 5\% (uji selang Duncan)

Perbedaan persentase penghambatan juga dapat dilihat pada Gambar 3 menunjukkan bahwa perlakuan AA 1\% mendekati perlakuan kontrol positif. Beda nyata terhadap kontrol negatif juga dapat dilihat pada perlakuan lain meskipun tidak mendekati perlakuan kontrol positif. Hasil ini menunjukkan bahwa perlakuan AA 1\% dapat menjadi tolak ukur sebagai perlakuan pestisida ramah lingkungan pengganti pestisida kimia. Selain aktivitas hambatan, pada gambar 3 dapat terlihat bahwa terdapat fenomena unik yang ditangkap dari hasil penelitian ini yaitu semakin menurunnya tingkat konsentrasi berbanding terbalik dengan area zona hambatan. Zona hambatan KT 0,6\% lebih kecil dari KT 0,4\% dan KT 0,2\%; begitu pula dengan AA 5\% zona hambatan lebih kecil dari AA 3\% dan AA 1\%. Raafat et al. (2008) menyebutkan bahwa aktivitas antimikroba dari chitosan dipengaruhi oleh beberapa faktor, salah satunya adalah dosis penggunaan dari chitosan. 


\section{TECHNO: Vol. 09 (02) Oktober 2020}

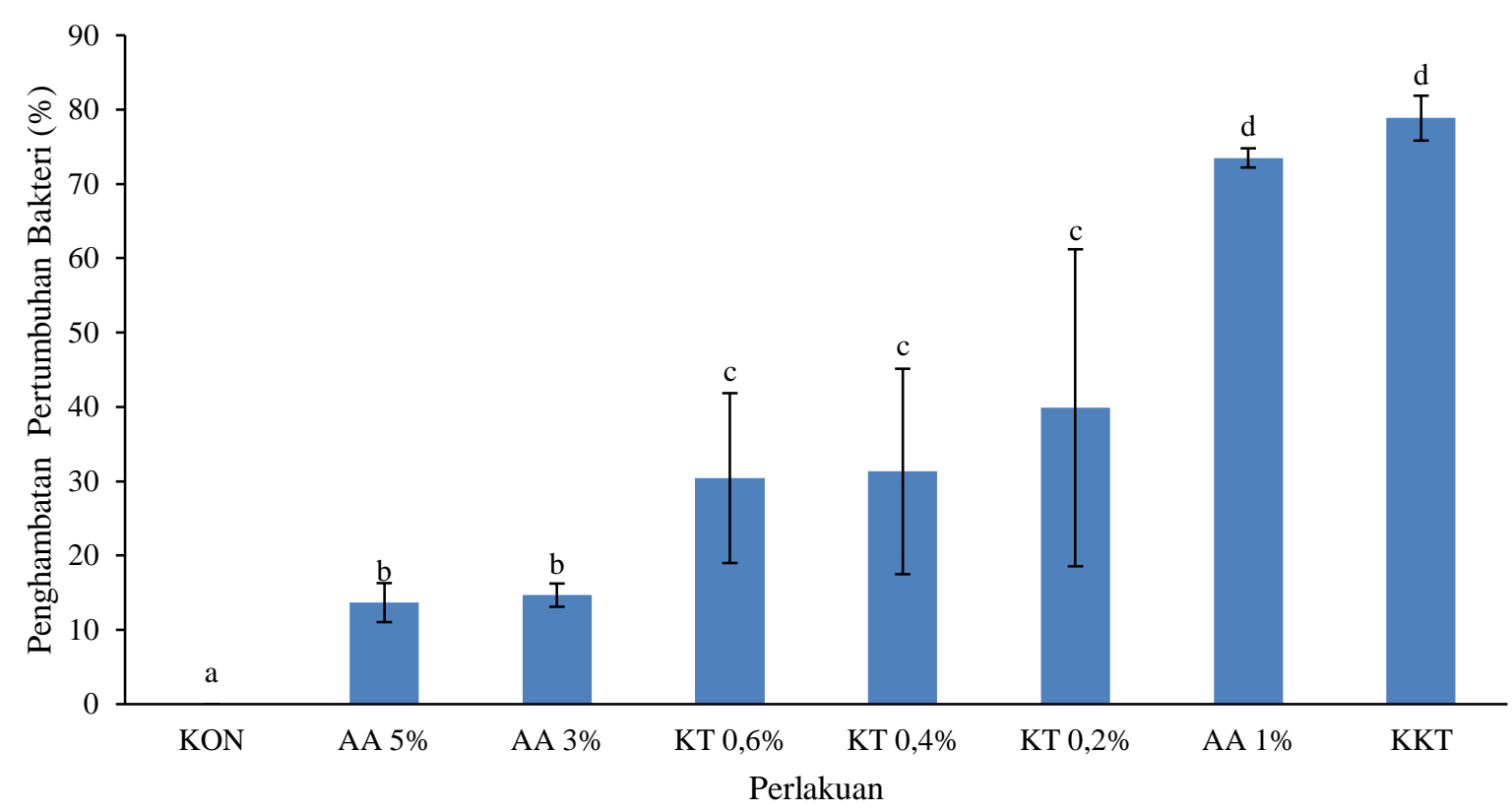

Gambar 3. Grafik persentase penghambatan pertumbuhan bakteri Xanthomonas oryzae pv. oryzae oleh perlakuan chitosan dan AMPs dengan berbagai konsentrasi.

Kemunculan perkembangan resistensi terhadap berbagai obat yang cepat, antibiotik konvensional tidak bisa membunuh bakteri patogen secara efisien, menyebabkan perlakuan antibiotik baru seperti AMPs dapat memberikan solusi untuk krisis resistensi antibiotik (Chung et al., 2020). Gabere and Noble (2017) juga menambahkan bahwa peningkatan barubaru ini pada resistensi mikroba terhadap obat saat ini telah menyebabkan peningkatan kebutuhan akan agen antimikroba seperti AMPs. Huang et al. (2017) menyebutkan bahwa AMPs secara alami dikodekan oleh gen dan umumnya mengandung 12-100 asam amino, merupakan komponen penting dari sistem kekebalan bawaan dan dapat melindungi inang dari berbagai bakteri dan virus patogen. Dalam beberapa tahun terakhir, penggunaan antibiotik secara luas telah menyebabkan pertumbuhan yang cepat terhadap resistensi mikroorganisme terhadap antibiotik yang sering menyebabkan infeksi dan tingkat patogenesis yang serius. AMPs mewakili efektor imun yang paling universal. AMPs dapat diambil dari berbagai organisme, salah satunya mollusca. Mollusca merupakan filum hewan terbesar kedua, setelah Arthropoda, dalam hal jumlah spesies. Sehingga pemanfaatan AMPs dari filum mollusca menjadi potensi tersendiri yang patut untuk dipertimbangkan.

Sama halnya dengan AMPs, chitosan merupakan merupakan sumber daya alam terbaharukan yang memiliki potensi besar di dunia pertanian. Chitosan dihasilkan dari produk limbah udang dan kepiting di industri pengalengan serta juga bisa didapat dari pengolahan limbah dari jamur, kerang, tiram, dan cumi-cumi (Tabel 2). Secara tradisional chitosan sangat penting karena memiliki sifat relatif persentase nitrogen besar (6,89\%) dibandingkan selulosa tersubstitusi sintesis (Mahmoud, El Kady, \& Asker, 2019). Ahmed, Ahmad, and Ikram (2014) menambahkan bahwa chitosan adalah polimer alami paling melimpah kedua setelah selulosa di dunia; kandungan primernya terdiri dari glukosamin dan residu glukosamin $\mathrm{N}$-asetil dengan ikatan 1, 4- $\beta$. Chitosan dianggap merupakan material paling menjanjikan untuk 
aplikasi masa depan karena kemampuannya yang baik dalam biodegradabilitas, biokompatibilitas, aktivitas antimikroba, non-toksisitas, dan keuntungan ekonominya.

Berdasarkan kajian chitosan dan AMPs sebagai antimikroba, potensi penggunaan chitosan dan AMPs di lapang sangatlah besar. Hal ini dikarenakan bakteri Xanthomonas oryzae pv. oryzae sesuai yang dikatakan oleh Agrios (2005) menyebutkan bahwa berdasarkan kemampuan patogen untuk berkembang menyebabkan pengendalian bakteri ini sangat sulit dilakukan. Satu-satunya pengendalian utama yang sangat mungkin dilakukan adalah menggunakan benih bebas penyakit atau benih yang diperlakukan dan rotasi tanaman. Namun penggunaan benih atau bibit bersertifikasi akan menjadi tidak relevan jika terdapat serangan hama yang membantu masuknya patogen ini kedalam tanaman, salah satu contohnya adalah hama dari golongan mollusca yaitu Apple snails. Apple snails (Ampullariidae: Pomacea) dikenal secara luas menjadi hama pertanian pada Asia bagian selatan dan timur sejak dikenalkan pada tahun 1980. (Hayes, Joshi, Thiengo, \& Cowie, 2008). Salleh, Arbain, Daud, Pilus, and Nawi (2012) mengatakan Golden apple snail ( $P$. canaliculata) atau yang disebut keong mas secara luas dipandang sebagai spesies hama invasif terburuk. $P$. canaliculata secara normal dapat menghancurkan batang muda dan daun padi dan dapat menggkonsumsi 7-24 bibit padi per hari, oleh karena itu dapat menghasilkan kerusakan ekstrim terhadap area penanaman padi. Pomacea canaliculata merupakan spesies yang terbanyak ditemukan di area pertanaman padi di Jawa Timur, selain merugikan ternyata spesies ini juga memiliki potensi yang terpendam. Mahmoud et al. (2019) mengatakan mollusca merupakan salah satu golongan yang dapat menjadi sumber kitin dan chitosan terbesar.

Tabel 3. Sumber kitin dan chitosan (Mahmoud et al., 2019).

\begin{tabular}{|l|l|l|}
\hline Sea Animals & Insects & Micro-Organisms \\
\hline Crustaceans & Scorpions & Green algae \\
\hline Coelenterate & Brachiopods & Yeast (betta - Type) \\
\hline Annelida & Cockroaches & Fungi (cell walls) \\
\hline Mollusca & Spiders & Mycelia penicillium \\
\hline Lobster & Beetles & Brown Algae \\
\hline Shrimps & Ants & Chytridiaceae \\
\hline Prawn & & Ascomydes \\
\hline Krill & & Blastocladiaceae \\
\hline Crab & & Spores \\
\hline
\end{tabular}

Keseluruhan mekanisme kerja chitosan sebagai antimikroba dapat didefinisikan sesuai dengan komponen target dari sel bakteri yang memiliki aktivitas utamanya. Jadi, tiga tingkat interaksi dapat dijelaskan sebagai berikut: (i) interaksi dengan komponen seluler luar, (ii) interaksi dengan membran sitoplasma dan (iii) interaksi dengan konstituen sitoplasma (Raafat \& Sahl, 2009). Raafat et al. (2008) menambahkan aktivitas antimikroba chitosan dipengaruhi oleh beberapa faktor, menunjukkan efek penghambatan pertumbuhan tergantung dosis. Sampai pada saat ini image keong mas masih terbatas hanya sebagai hama pada tanaman padi sehingga keong mas jarang diolah atau dimanfaatkan dalam bentuk lain. Namun jika dilihat dari struktur tubuh keong mas, hewan ini memiliki potensi luar biasa yang dapat dikembangkan seperti pada penelitian ini. 


\section{TECHNO: Vol. 09 (02) Oktober 2020}

\section{KESIMPULAN}

Perlakuan chitosan dan AMPs memiliki potensi yang sangat baik sebagai antibakteri ramah lingkungan dengan bahan baku melimpah yang ditunjukkan oleh perlakuan terbaik yaitu AMPs 1\%. Berdasarkan pembahasan menunjukkan baik chitosan dan AMPs memiliki kandungan antimikroba sehingga baik chitosan maupun AMPs memiliki daya hambat yang baik terhadap bakteri. Semakin banyaknya penelitian baru terkait antibakteri ramah lingkungan akan menjadi titik balik dalam dunia pengembangan antimikroba.

\section{UCAPAN TERIMA KASIH}

Penulis menyampaikan ucapan terima kasih kepada LP2M Universitas Jember atas pendanaan penelitian sehingga penelitian ini dapat terlaksana dengan baik.

\section{DAFTAR PUSTAKA}

Agrios, G. N. (2005). Plant Pathology. 5th ed. London: Elsevier Academic Press.

Ahmed, S., Ahmad, M., \& Ikram, S. (2014). Chitosan: a natural antimicrobial agent-a review. $J$ Journal of Applicable Chemistry, 3(2), 493-503.

Ambarwati. (2007). Efektivitas Zat Antibakteri Biji Mimba (Azadirachta indica) ntuk Menghambat Pertumbuhan Salmonella thyposa dan Staphylococcus aureus. Biodiversitas, 8(3), 320-325. doi:10.13057/biodiv/d080415

Azam Baihaqi, M. (2017). Pembuatan dan Uji Potensi Kitosan Cangkang Rajungan Sebagai Bahan Pelindung Buah Cabai Merah (Capsicum annum L.) dari Serangan Penyakit Antraknosa. (Skripsi), Universitas Jember, Jember.

Chellaram, C., Gnanambal, K. M. E., \& Edward, J. K. P. (2004). Antibacterial Activity of The Winged Oyter Pteria chinensis (Pterioida: Pteridae). Indian Journal of Marine Sciences, 33(4), 369-372.

Chung, C.-R., Jhong, J.-H., Wang, Z., Chen, S., Wan, Y., Horng, J.-T., \& Lee, T.-Y. (2020). Characterization and Identification of Natural Antimicrobial Peptides on Different Organisms. J International Journal of Molecular Sciences, 21(3), 986.

Degiam, Z. D., \& Abas, A. T. (2010). Antimicrobial activity of some crude marine Mollusca extracts against some human pathogenic bacteria. Thi-Qar Medical Journal, 4(3), 142147.

Gabere, M. N., \& Noble, W. S. (2017). Empirical comparison of web-based antimicrobial peptide prediction tools. J Bioinformatics, 33(13), 1921-1929.

Haszprunar, G. (2001). Mollusca (Molluscs). In Encyclopedia of Life Sciences. Munich: John Wiley \& Sons, Ltd.

Hayes, K., Joshi, R., Thiengo, S., \& Cowie, R. (2008). Out of South America: multiple origins of non-native apple snails in Asia. Diversity and Distributions, 14(4), 701-712.

Huang, K.-Y., Chang, T.-H., Jhong, J.-H., Chi, Y.-H., Li, W.-C., Chan, C.-L., . . . Lee, T.-Y. (2017). Identification of natural antimicrobial peptides from bacteria through metagenomic and metatranscriptomic analysis of high-throughput transcriptome data of Taiwanese oolong teas. J BMC systems biology, 11(7), 131.

Kelman, D., Kuhmaro, A., Loya, Y., Kashman, Y., \& Benayahu, Y. (1998). Antimicrobial activity of a Red Sea soft coral, Parerythropodium fulvum fulvum: reproductive and developmental considerations. Marine Ecology Progress Series, 169, 87-95. 
Khoirunnisya. (2009). Potensi Bakterisida Senyawa Metabolit Penicillium spp. Terhadap Ralstonia solanacearum Penyebab Penyakit Layu Bakteri Pada Cabai. (Skripsi), Institut Pertanian Bogor, Bogor.

Khush, G. S., \& Jena, K. (2009). Current status and future prospects for research on blast resistance in rice (Oryza sativa L.). In G.-L. Wang \& B. Valent (Eds.), Advances in genetics, genomics and control of rice blast disease (pp. 1-10): Springer.

Kumaran, N. S., Bragadeeswaran, S., \& Thangaraj, S. (2011). Screening for antimicrobial activities of marine molluscs Thais tissoti (Petit, 1852) and Babylonia spirata (Linnaeus, 1758) against human, fish and biofilm pathogenic microorganisms. African Journal of Microbiology Research, 5(24), 4155-4161.

Mahmoud, M. G., El Kady, E. M., \& Asker, M. S. (2019). Chitin, Chitosan and Glucan, Properties and Applications. World Journal of Agriculture and Soil Science, 3(1), 1-19.

Pal, K. K., \& McSpadden Gardener, B. (2006). Biological Control of Plant Pathogens. The Plant Health Instructor 2006: 1-25. doi:10.1094/phi-a-2006-1117-02

Raafat, D., \& Sahl, H. G. (2009). Chitosan and its antimicrobial potential-a critical literature survey. J Microbial biotechnology, 2(2), 186-201.

Raafat, D., Von Bargen, K., Haas, A., \& Sahl, H.-G. (2008). Insights into the Mode of Action of Chitosan as an Antibacterial Compound. J Applied and Environmental Microbiology, 74(12), 3764-3773.

Rabea, E. I., Badawy, M. E.-T., Stevens, C. V., Smagghe, G., \& Steurbaut, W. (2003). Chitosan as Antimicrobial Agent: Applications and Mode of Action. J Biomacromolecules, 4(6), 1457-1465.

Salleh, N. H. M., Arbain, D., Daud, M. Z. M., Pilus, N., \& Nawi, R. (2012). Distribution and management of Pomacea canaliculata in the Northern Region of Malaysia: Mini Review. Apcbee Procedia, 2, 129-134.

Wahyudi, A. T., Meliah, S., \& Nawangsih, A. A. (2011). Xanthomonas oryzae pv. oryzae bakteri penyebab hawar daun pada padi: isolasi, karakterisasi, dan telaah mutagenesis dengan transposon. Makara Journal of Science. 